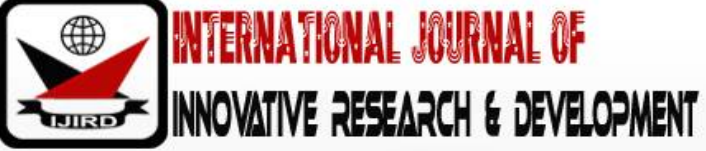

ISSN 2278 - 0211 (Online)

\section{Effect of Innovation Strategy on Organizational Performance in the Milk Processing Companies in Rwanda: A Case of Inyange Industry}

\author{
Janet Mutheu Kasyoka \\ Student, Jomo Kenyatta University of Agriculture and Technology, Kenya \\ Dr. Patrick Mulyungi \\ Student, Jomo Kenyatta University of Agriculture and Technology, Kenya
}

\begin{abstract}
:
Innovation often referred to as creativity of processes, products and services within a firm. This therefore indicates that Inyange industry to be highly competitive in the Rwanda market needs to continuously innovate based on the products that satisfy the market it operates for it to meet its financial performance target and thus fulfill its well indicated mission. This study therefore sought to examine effect of innovation strategy on organizational performance in milk processing companies in Rwanda. Specifically, the study sought to; examine the effect of product, process and market innovation strategy on performance in milk processing companies in Rwanda. The study adopted a descriptive research design. 156 respondents as population, was stratified into three strata: finance managers, production managers, and operational managers. From each stratum the study used the stratified sampling technique to reach to the entire population of the study. Data was collected from both primary and secondary data using questionnaires and documentation. Data collected was analyzed using SPSS version 21. Data analysis involved statistical computations for averages, percentages, and correlation and regression analysis. Ordinary least squares (OLS) regression method of analysis was adopted to determine the inferential statistics. From the above, holding Product Innovation, Process Innovation, Market Innovation to a constant zero, organizational performance would be at 0.347 . Unit increase on Product Innovation would lead to increase in organizational performance by a factor of 0.162 , unit increase in Process Innovation would lead to increase in financial performance by a factor of 0.282, a unit increase in Market Innovation would lead to increase in organizational performance by a factor of 0.194 . This means that product innovation strategy has a great impact on the performance as per the correlation analysis. Also, an improvement in product innovation brought about great performance as per the multiple regression analysis. Thus, as per the regression analysis, market innovation is vital for greater performance. In conclusion, among the strategies, product innovation had more impact and process innovation had less impact on the performance of Inyange industry.
\end{abstract}

Key words: Product innovation, process innovation, market innovation, Inyange industry, milk processing companies in Rwanda

\section{Background}

Internationally, creativity is viewed as process where organizations learn the art of creativity and ensure implementation of new and improved designs of the products or services regardless of whether they are new to their competitors (Mytelka, 2010). More so, Basterretxea and Ricardo Martinez, (2012) discuses innovation as continually improving by employing new knowledge or the new combination of existing knowledge that is new to the local area whereby, various types such as product, marketing, research and development innovations are observed.

Innovation has been a longstanding concern particularly in the European Union where there is widespread perception that there are more difficulties raising finance for innovation than in the US (Nugroho \& Mile, 2009). It is further pointed out that manufacturing companies have a distinct advantage in process and product innovation to meet the requirements of poor clients. Innovations arise in competitive conditions as manufacturing companies attempt to tackle the challenge of developing products and services suitable to their customers, of expanding and maintaining market shares.

D'cruz and Rugman (2012) argue that an organization is in competition if it ensures that the products and services are of high quality than those provided by its competitors. According to Kaplan and Warren (2017) organizations should not only use innovation as a luxury but is a necessity. Most studies focus on the performance and innovation association give a positive appraisal of higher innovativeness that leads to increased firm performance. Shqipe, Gadaf and Veland (2013), opined that there are distinctively two types of innovations; these are incremental and radical innovations. Yilmaz et al. (2015) described that there are four dimensions are used to measure innovation performance in organizations. 
These include market performance, innovative performance, financial performance and innovative performance. Innovations have an effect on corporate performance by producing enhanced market position that shows superior performance and competitive advantage (Gunday, Ulusoy Kilic \& Alpkan, 2011).

Organizational performance can be measured through non-financial and financial means (Bagorogoza \& Waal, 2010; Bakar \& Ahmad, 2010). Majority of organization often prefer to use financial means to measure their performance. Average annual occupancy rate, net profit after tax, Return on Assets (ROA) and Return on Investment (ROI) are the mostly used means of measuring organization performance Tavitiyaman et al. (2012). However, other used measures are of firm performance include profitability, productivity, growth, stakeholder satisfaction, market share and competitive position (Bagorogoza \& Waal, 2010). Moreover, other researchers have proposed other indicators as such as being able to combine non-financial measurements to meet the changes of external and internal environments (Krager \& Parnell, 2016). Inyange Industries is a leading milk processing company in Rwanda, manufacturing a variety of products under their brand name- "Inyange". Masaka Farms Dairy was started in May 2008 and as a small-scale production of yogurt and fresh cream. On 10th January 2010 Masaka Farms Ltd was incorporated with main principal activity of producing dairy products notably yogurt, fresh cream, cheese and butter. Although, the Inyange brand has been operating since 1997 it wasn't until 1999 when it began operations including processing \& selling pasteurized milk \& yoghurt. In 2001 the plant introduced mineral water processing \& packaging. It takes $80 \%$ in mineral water, $70 \%$ in juices, $65 \%$ in pasteurized milk, $5 \%$ in UHT and 70\% in Yoghourt (Inyange Industries, 2010:2). On average, the company holds more than 60\% of the total market share of domestic agro-processing industry products. The company's objective is aligned with the Government's priorities, since the Government of Rwanda committed respectively 10\% and 15\% of its 2010/2011 and 2011/2012 (MINECOFIN, 2011) budgets to agriculture, aiming at ensuring food security and price sustainability whilst maintaining sustainable growth. Inyange Industries has a vision which is "to be a leading beverage brand producing high quality products while enhancing shareholder value in producing high quality products that satisfy and exceed customers' expectations while enhancing shareholder value" (Inyange Industries, 2010).

\subsection{Statement of the Problem}

Manufacturing is the backbone of any industrialized nation. Recent worldwide advances in manufacturing technologies have brought about a metamorphosis in industry. Fast-changing technologies on the product front have created a need for an equally fast response from manufacturing industries. To meet these challenges, manufacturing industries have to select appropriate decisions, product designs, manufacturing processes, work piece and tool materials, and machinery and equipment. The selection decisions are complex, as decision making is more challenging today. The need for innovation is obvious and crucial for manufacturing companies operating in a continuous uncertain and competitive environment. Most importantly, to survive and succeed in the current competitive global financial environment, manufacturing companies need to be innovative by producing a regular stream of innovations so as to gain competitive advantage (MINECOFIN, 2010). Many manufacturing companies have at some point undertaken some form of incremental innovative initiatives.

Kariuki's (2010) research on process innovation and positive performance focused on commercial banks as opposed to MFIs while Mugo (2012) focused on MFI institutional innovativeness. Chemitei (2012) focused on role of innovation in creating competitive advantage in MFIs and not on performance while Mwangi (2014) focused on effect of financial innovation on financial returns of deposit taking MFIs in Kenya. Inyange Industries has a clear vision which is "to be a leading beverage brand producing high quality products while enhancing shareholder value in producing high quality products that satisfy and exceed customers' expectations while enhancing shareholder value".

Realizing that the domestic demand for all Inyange products was much higher than the facilities could supply, Inyange's shareholders embarked on an ambitious expansion project, the construction of a USD 27 Million production plant in Masaka, which has since allowed for Inyange's production capacity to increase tenfold. In modern \& hygienic production facilities, Inyange manufactures a wide range of products \& thus has quickly become a household name in the fast-moving consumer goods industry in Rwanda. This therefore indicates that Inyange industry to be highly competitive in the Rwanda market and its regions needs to continuously innovate based on the products that satisfy the market it operates for it to meet its financial performance target. Currently, there is no known study that has focused on extent determining effect of innovation strategy on performance of milk processing companies in Rwanda. This study therefore sought to fill this knowledge gap by answering the question what are effect of innovation strategies on performance of milk processing companies in Rwanda?

\subsection{Objectives of the Study}

\subsubsection{General Objective}

The main objective of this study was to investigate effect of innovation strategy on organizational performance in milk processing companies in Rwanda.

\subsubsection{Specific Objectives}

To determine the effect of product innovation strategy on organizational performance in the milk processing companies in Rwanda. 


\section{Conceptual Framework}

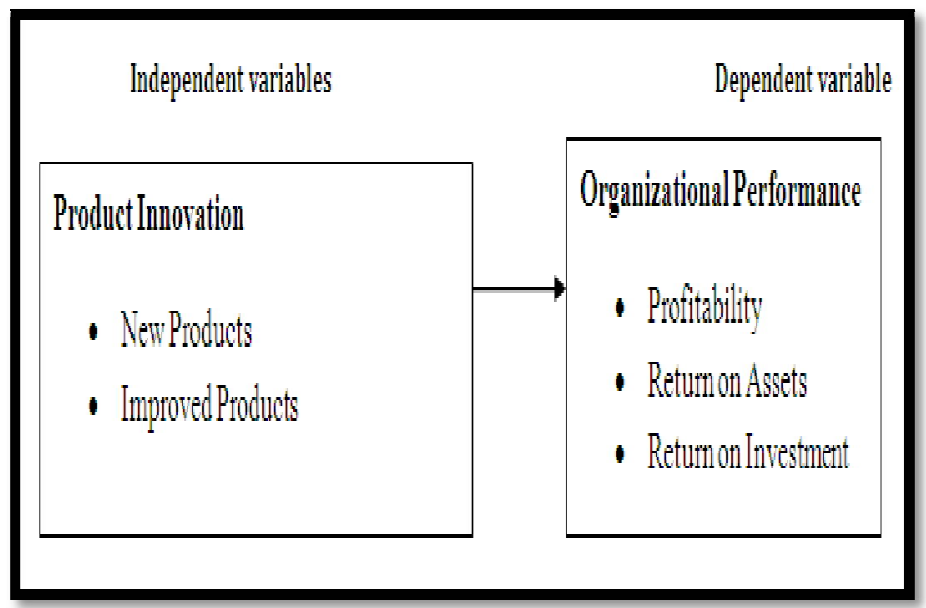

Figure 1 Conceptual Framework

\section{Target Population}

According to Bryman \& Bell, (2011) population is the entire group of people put together by a common feature and from where a sample would be drawn. This individual consisted of all Inyange industry employees working at the decision-making levels since they are the ones involved in laying out the strategies. The target population was 156 respondents.

\subsection{Sampling Procedure}

The 156 population was sampled. Stratified random sampling was used. The sample size was statistically calculated using Slovin's formula $\left(n=N / 1+N(e)^{2}\right.$

Where;

$\mathrm{n}$ is the sample size,

$\mathrm{N}$ is the population size (156)

$\mathrm{e}$ is the desired level of precision (0.05)

$\mathrm{n}=156 / 1+156(0.05)^{2}=113$

\begin{tabular}{|c|c|c|}
\hline Department & Population & Sample \\
\hline Finance managers & 12 & 9 \\
\hline Accountants & 48 & 35 \\
\hline Logistics managers & 96 & 69 \\
\hline Total & 156 & 113 \\
\hline \multicolumn{2}{|c|}{ Table 1: Sampling Frame }
\end{tabular}

\section{Research Findings and Discussion}

\subsection{Product Innovation on Organizational Performance}

Table 2 indicates effect of product innovation on performance at Inyange industry according to the respondents.

\subsubsection{Descriptive Statistical Analysis of Product Innovation}

The study sought the view of the respondents in regard to product innovation strategy in Inyange industries. Respondents' opinion on product innovation with regard to Inyange industry performance was captured using 1 - Strongly disagree; 2 - Disagree; 3 - Indifferent; 4 - Agree; 5 - Strongly agree. Respondents' opinions and their percentages are as shown below: 


\begin{tabular}{|c|c|c|c|c|c|c|c|}
\hline Statements & $\mathbf{1}$ & $\mathbf{2}$ & $\mathbf{3}$ & $\mathbf{4}$ & $\mathbf{5}$ & $\mathbf{M e a n}$ & $\begin{array}{c}\text { Std. } \\
\text { Dev }\end{array}$ \\
\hline $\begin{array}{c}\text { Inyange industries offers high quality items to their } \\
\text { customers }\end{array}$ & $6.2 \%$ & $7.2 \%$ & $8.2 \%$ & $30.9 \%$ & $47.4 \%$ & 4.06 & 1.19 \\
\hline $\begin{array}{c}\text { Inyange industries increases manufacturing quality } \\
\text { in components of current products }\end{array}$ & $4.1 \%$ & $4.1 \%$ & $3.1 \%$ & $42.3 \%$ & $46.4 \%$ & 4.23 & 0.99 \\
\hline $\begin{array}{c}\text { The product performance is relatively high } \\
\text { compared to other manufacturing companies }\end{array}$ & $11.3 \%$ & $7.2 \%$ & $8.2 \%$ & $28.9 \%$ & $44.3 \%$ & 3.88 & 1.36 \\
\hline $\begin{array}{c}\text { The products offered by Inyange industries are } \\
\text { highly differentiated. }\end{array}$ & $7.2 \%$ & $12.4 \%$ & $13.4 \%$ & $42.3 \%$ & $24.7 \%$ & 3.64 & 1.19 \\
\hline $\begin{array}{c}\text { Inyange industries designs product functionalities } \\
\text { totally differing from the current ones }\end{array}$ & $4.1 \%$ & $7.2 \%$ & $8.2 \%$ & $37.1 \%$ & $43.3 \%$ & 4.08 & 1.09 \\
\hline $\begin{array}{c}\text { Inyange industries increases manufacturing quality } \\
\text { materials of current products }\end{array}$ & $6.2 \%$ & $10.3 \%$ & $9.3 \%$ & $27.8 \%$ & $46.4 \%$ & 3.98 & 1.24 \\
\hline $\begin{array}{c}\text { Inyange industries develops new products with } \\
\text { components totally differing from current ones. }\end{array}$ & $5.2 \%$ & $8.2 \%$ & $12.4 \%$ & $32.0 \%$ & $42.3 \%$ & 3.98 & 1.16 \\
\hline $\begin{array}{c}\text { Inyange industries develops new products for to } \\
\text { improve customer satisfaction }\end{array}$ & $4.1 \%$ & $7.2 \%$ & $6.2 \%$ & $34.0 \%$ & $48.5 \%$ & 4.15 & 1.09 \\
\hline $\begin{array}{c}\text { Inyange industries decreases manufacturing costs in } \\
\text { components of current products }\end{array}$ & $7.2 \%$ & $3.1 \%$ & $6.2 \%$ & $40.2 \%$ & $43.3 \%$ & 4.09 & 1.12 \\
\hline
\end{tabular}

Table 2: Product Innovation on Performance

In terms of effect of market innovation on performance at Inyange industries, the highest observed mean was Improving service quality is one of our key objectives of our market innovation strategy $(\mathrm{M}=3.59 ; \mathrm{SD}=1.364)$. This was followed by our market innovation and way of operation is the most suitable for delighting our customers ( $\mathrm{M}=3.39$; $\mathrm{SD}=1.836)$ and the company competitiveness has increased greatly since the introduction of market innovation ( $M=3.10$; $\mathrm{SD}=1$.236). The least mean score items on effect of market innovation on performance was formulating market innovation increases employee knowledge and skills $(\mathrm{M}=1.82$; $\mathrm{SD}=1.262)$ followed by Market innovation strategy has helped the organization to achieve its strategic goals $(\mathrm{M}=2.30 ; \mathrm{SD}=1.365)$ and Internal cooperation is an important part of market innovation strategy ( $\mathrm{M}=2.51 ; \mathrm{SD}=1.622)$.

\subsubsection{Correlation Analysis Product Innovation}

Correlation analysis was conducted to empirically determine whether product innovation was a significant determinant of organization performance.

\begin{tabular}{|c|c|c|c|}
\hline \multicolumn{2}{|c|}{} & $\begin{array}{c}\text { Product } \\
\text { Innovation }\end{array}$ & $\begin{array}{c}\text { Organization } \\
\text { Performance }\end{array}$ \\
\hline \multirow{3}{*}{$\begin{array}{c}\text { Product } \\
\text { innovation }\end{array}$} & Pearson Correlation & 1 & \\
\cline { 2 - 4 } & Sig. (2-tailed) & & \\
\cline { 2 - 4 } & $\mathrm{N}$ & 97 & \\
\hline \multirow{2}{*}{$\begin{array}{c}\text { Organization } \\
\text { performance }\end{array}$} & Pearson Correlation & $.518^{* *}$ & 1 \\
\cline { 2 - 4 } & Sig. (2-tailed) & .000 & 97 \\
\cline { 2 - 4 } & $\mathrm{N}$ & 97 & 97 \\
\hline
\end{tabular}

Table 3: Correlation Analysis on Product Innovation

**. Correlation Is Significant at the 0.01 Level (2-Tailed)

Table 3 indicate that Product innovation is significantly correlated to the Inyange industry performance ( $\mathrm{r}=0.518$, $\mathrm{p}<0.01$ ). This shows that the sampled data can be applied to the general population across manufacturing companies at 95\% confidence level.

\subsubsection{Regression Analysis - Product Innovation on Performance}

Regression analysis was conducted to empirically determine whether product innovation was a significant determinant of performance. Regression results in Table 4.8 indicate the goodness of fit for the regression between product innovation and performance was satisfactory in the linear regression.

An R squared of 0.312 indicates that $31.2 \%$ of the variances in performance of Inyange industry are explained by the variances in product innovation in the linear model. The correlation coefficient of $51.8 \%$ shows the predictor variables has a positive correlation with performance. 


\begin{tabular}{|c|c|c|c|c|}
\hline Model & R & R Square & Adjusted R Square & Std. Error of the Estimate \\
\hline 1 & $.442^{\mathrm{a}}$ & .301 & .312 & .65724 \\
\hline
\end{tabular}

Table 4: Model Summary

a. Predictors: (Constant), Product Innovation

Result review that product innovation is statistically significant in explaining performance of Inyange industry in Rwanda. An F statistic of 5.020 indicated that the combined model was significant. From the analysis, a p-value less than 0.05 ( $\mathrm{p}$-value $=0.0000$ ) was obtained. This implies that the simple linear model with product innovation as the only independent variable is significant.

\begin{tabular}{|c|c|c|c|c|c|c|}
\hline \multicolumn{2}{|c|}{ Model } & Sum of Squares & Df & Mean Square & F & Sig. \\
\hline \multirow{3}{*}{1} & Regression & 12.14 & 1 & 12.14 & 5.020 & $.000^{\mathrm{a}}$ \\
\cline { 2 - 7 } & Residual & 28.684 & 49 & .476 & & \\
\cline { 2 - 7 } & Total & 40.824 & 50 & & & \\
\hline
\end{tabular}

Table 5: Anova Results Showing Effect of Product Innovation on Performance Anova ${ }^{\mathrm{b}}$

a. Dependent Variable: Organizational Performance

b. Predictors: (Constant), Product Innovation

Correlation coefficients show that product innovation $(\mathrm{X} 1)$ is significant ( $\mathrm{p}$-value $=0.0000$ ) in influencing organizational performance (Y). Results are shown in Table 4.10 and the fitted model from this analysis is shown below: $\mathrm{Y}=2.487+0.342 \mathrm{X} 1$

\begin{tabular}{|c|c|c|c|c|c|c|}
\hline Model & & \multicolumn{2}{|c|}{$\begin{array}{c}\text { Unstandardized } \\
\text { Coefficients }\end{array}$} & $\begin{array}{c}\text { Standardized } \\
\text { Coefficients }\end{array}$ & t & Sig. \\
\hline 1 & & B & Std. Error & Beta & & \\
\hline & (Constant) & 2.487 & .270 & & 7.169 & .000 \\
\hline & $\begin{array}{c}\text { Product } \\
\text { innovation }\end{array}$ & .342 & .062 & .444 & 2.241 & .000 \\
\hline
\end{tabular}

Table 6: Coefficient Results Showing the Relationship between

Product Innovation and Performance Coefficients (A)

a. Dependent Variable: Organizational Performance

\section{Conclusions}

The study reaffirmed that there is a positive and significant relationship between product innovation and performance of the milk processing companies in Rwanda. The study therefore concludes that there is a positive and significant effect of product innovation strategy on performance of Inyange industry. The study further concludes that among the innovation strategies included in the study, product innovation strategy had the most influence on performance of the milk processing companies in Rwanda.

\subsection{Recommendation.}

Inyange industry to continuously engage in product innovation to enhance the competitive advantage it possesses against other players in the manufacturing sector. This can be achieved by conducting market research among its users and non-users to identify products that they can introduce into their product catalogue.

The study recommends that Inyange industry should consistently analyze and measure their services operations in an effort to enhance operations efficiency.

The study recommends that to increase number of customers and for Inyange industry business to grow further and also for them to invest more in consumers. That Inyange industry should embrace the adoption of market innovation strategies by taking advantage of the numerous communication technologies and mediums to reach a larger audience.

\subsection{Areas for Further Research}

The purpose of the study was to examine the effects of innovation strategy on organizational performance in the milk processing companies in Rwanda industry taking Inyange industry as a case. A comparative study of innovation strategies and how manufacturing firms are using them and what impact they have had on their performance

\section{References}

i. Abate, J.A., Grant, J.L., \& Stewart III, G.B. (2014). The EVA style of investing: Emphasizing the fundamentals of wealth creation. Journal of Portfolio Management, 30(4), 61-72.

ii. Abbing, E. R. (2010). Brand-driven Innovation. SA: AVA Publishing

iii. Addai, B., \&Pu, C. (2015). The impact of delinquent loans on performance of banks in Ghana. British Journal of Economics, Management \& Trade, 9(2), 1-8. 
iv. Adhikary, S. (2014). Performance of microfinance institutions and outreach to the poor in South Asia. PhD Thesis. Aristotle University of Thessaloniki: Thessaloniki, Greece.

v. Adner, R., \& Levinthal, D. (2011). Demand heterogeneity and technology evolution: Implications for product and process innovation. Management Science, 47 (5), 611-628.

vi. Alegre, J., Lapiedra, R. \& Chiva, R. (2016). A Measurement Scale for Product Innovation Performance, European Journal of Innovation Management, 9 (4), 333-346

vii. Anderson, K. (2010). How Increased EU Import Barriers and Reduced Retail Margins

viii. Affect the World Wine Market, Australian and New Zealand Wine Industry Journal, 16 (3), 69-74

ix. Anderson K, \& Nelgen, S. (2011). How valuable are the various quality segments of the world's wine markets? Wine Economics Research Centre, School of Economics, University of Adelaide

x. Artz, K. W., Norman, P. M., Hatfield, D. E. \& Cardinal, L. B. (2010). A longitudinal study of the impact of R \& D, patents, and product innovation on firm performance,Journal of Product Innovation Management, 27 (5) , 725-740.

xi. Atalaya, M., Anafarta, N. \& Sarvanc, F. (2013). The relationship between innovation and

xii. firm performance: An empirical evidence from Turkish automotive supplier industry, Procedia - Social and Behavioral Sciences, 75, 226 - 235

xiii. Atieno, M.D. (2013). Effect of microfinance innovations on access to finance by small and medium enterprises in Kenya: A case of microfinance institutions in Kenya. Unpublished MBA project, University of Nairobi, Kenya.

xiv. Bagorogoza, J. \& Waal, A. D. (2010). The Role of Knowledge Management in Creating

xv. and Sustaining High Performance Organizations the Case of Financial Institutions in Uganda, World Journal of Entrepreneurship Management and Sustainable Development, 6 (4), 307-323

xvi. Bakar, L. J. A. \& Ahmad, H. (2010). Assessing the Relationship between Firm Resources and Product Innovation Performance, Business Process Management Journal, 16 (3), 420-435.

xvii. Basterretxea, I., \& Martinez, R. (2012). Impact of management and innovation capabilities on performance: Are cooperatives different. Annals of Public and Cooperative Economics, 83 (3), 357-381.

xviii. Bayus, B. L., Erickson, G., \& Jacobson, R. (2013). The financial rewards of new product introductions in the personal computer industry. Management Science, 49 (2), 197-210.

xix. Berlyne, D.E. (2012). Uncertainty and epistemic curiosity. British Journal of Psychology, 53, 27-34.

xx. Blach, J. (2011). Financial innovations and their role in the modern financial system - identification and systematization of the problem. Financial Internet Quarterly e-Finance, 7(3), 13-26.

xxi. Boachie-Mensah, F., \& Acquah, I.S.K. (2015). The effects of innovation types on the performance of small and medium-sized enterprises in the Sekondi-Takoradi metropolis. Archives of Business Research, 3(3), 77-98.

xxii. Bowen, F. E., Rostami, M. \& Steel, P. (2010). Timing is everything: A meta-analysis of the relationships between organizational performance and innovation, Journal of Business Research, 63 (11), 1179-1185

xxiii. Bryman, B. \& Bell, E. (2011). Business Research Methods (3rd Ed.). Oxford, UK: Oxford University Press.

xxiv. Calantone, R. J., Harmancioglu, N. \& Droge, C. (2010). Inconclusive innovation "returns": A meta-analysis of research on innovation in new product development, Journal of Product Innovation Management, 27 (7), 1065-81

xxv. Chemitei, L.J. (2012). The role of product innovations in creating competitive advantage: A case of microfinance institutions in Nakuru town. Unpublished MBA project, Kabarak University, Kenya.

xxvi. Chen, Sh. \& Dodd, J. (2012). Market efficiency, CAPM, and value-relevance of earnings and EVA: A reply to the comment by professor Paulo. Journal of Managerial Issues, 14(4), 507-512.

xxvii. Cooper, D.R., \& Schindler, P.S. (2013). Business research methods, 10th Ed., New York, McGraw-Hill.

xxviii. Dary, S.K., \& Issahaku, H. (2013). Exploring innovations in microfinance institutions in

xxix. Northern Ghana. Business and Economic Research, 3(1), 442-460.

xxx. D'Cruz, J. \& Rugman, A. (2012). New Concepts for Canadian Competitiveness. Canada: Kodak

xxxi. Defaria, P. \& Mendonça, J. (2011). Innovation strategies by firms: Do innovative firms grow more, International Journal of Entrepreneurship and Small Business, 12 (2), 173-84.

xxxii. Frame, W., \& Lawrence, J. (2011). The diffusion of financial innovation: an examination of the adoption of small business credit scoring by large banking, 1187-1240.

xxxiii. Gunday, G., Ulusoy, G., Kilic, K. \& Alpkan, L. (2011). Effects of innovation types on firm performance, International Journal of Production Economics, 133 (2), 662-676

xxxiv. Hatfield, G. (2012). R\&D in an EVA world. Research Technology Management, 45(1),41-47.

xxxv. Hernandez-Espallardo, M. \& Delgado-Ballester, E. (2009). Product innovation in small manufacturers, market orientation and the industry's five competitive forces: Empirical evidence from Spain. European Journal of Innovation Management, 12 (4), 470-491

xxxvi. Hurley, R. F. \& Hult, G. T. M. (2018). Innovation, Market Orientation and Organizational, Industrial Marketing Management, 24 (5), 439-456.

xxxvii. Imali, A.J. (2013). Determinants of performance of microfinance institutions in Nairobi Kenya. Unpublished Masters project in Banking and Finance. Moi University, Eldoret, Kenya.

xxxviii. Inyange Industries LTD (2010), Strategic Business Plan for Inyange Industries, Kigali

xxxix. Jimenez, J.D., \& Sanz-Valle, R. (2011). Innovation, organizational learning and performance. Journal of Business research, 64(4), 408-417.

xl. Johne, A. (2013). Innovation types and innovation management practices in service companies, International Journal of Operations \& Production Management, 27 (6), 564-587

xli. Johne, A., \& Storey, C. (2008). New Service Development. European Journal of Marketing, 32 (3/4), 184-251. 
xlii. Kagan, A., Acharya, R. N., Rao, L. S., \& Kodepaka, V. (2015). Does internet banking affect the performance of community banks? Selected Paper prepared for presentation at the American Agricultural Economics Association Annual Meeting, Providence, Rhode Island, 24-27.

xliii. Kaplan, M. J. and Warren, A. C. (2017). Patterns of Entrepreneurship (2nd Ed.). New York, NY: John Wiley and Sons Inc

xliv. Kariuki, F.W. (2010). The relationship between financial engineering and financial performance of commercial banks in Kenya. Unpublished MBA project, University of Nairobi, Nairobi, Kenya.

xlv. Kibachia, J. (2014). A survey of risk factors in the strategic planning process of parastatals in Kenya. European Journal of Business and Innovation Research Vol.2, No.3, pp. 51-67.

xlvi. Kombo, D.K., \& Tromp, D.L.A. (2009). Proposal and thesis writing: An introduction. Nairobi. Paulines Publications Arica.

xlvii. Kothari, C. (2014). Research methodology: Methods and Techniques. (3rd ed.). New Delhi: New Age International.

xlviii. Lin, C. H., Peng, C. H. \& Kao, D. T. (2017). The Innovativeness Effect of Market Orientation and Learning Orientation on Business Performance, International Journal of Manpower, 29 (8), 752-772

xlix. Mabrouk, A., \& Mamoghli C. (2010). Is financial innovation influenced by financial liberalization? Evidence from the Tunisian banking industry. Banks Systems Journal, 5(3), 45-50.

1. Minai, M. S. \& Lucky, E. O. (2011). The Conceptual Framework of the Effect of Location on Performance of Small Firms. Asian Social Science, 7 (12), 110- 117

li. MINECOFIN (2010), National Budget 2010/ 2011, Kigali, June 2010

lii. Mugo, J.G. (2012). The effect of financial innovation on the growth of micro-finance Institutions in Kenya. Unpublished MBA project, University of Nairobi, Kenya.

liii. Mugenda, O. M., \& Mugenda, A. G. (2008). Research methods: Quantitative and qualitative approaches. NairobiKenya: Acts Press.

liv. Mugenda, O.M., \& Mugenda, A.G. (2013). Research methods. Nairobi: McMillan Publishers.

lv. Mwangi, J.M. (2014). The Effect of Financial Innovation of Financial Returns of Deposit Taking Microfinance Institutions in Kenya. MBA research project, University of Nairobi, Kenya.

lvi. Mytelka, L. K. (2010). Local systems of innovation in a globalized world economy. Industry and Innovation, 7(1), 15-32.

lvii. Neely, A. D. (2012). Business Performance Measurement: Theory and Practice. Cambridge, UK: Cambridge University Press.

lviii. NISR (2012), 2012 Population and Housing Census, Provisional results, Kigali

lix. Nugroho, Y., \& Miles, I. (2009). Global Review of Innovation Intelligence and Policy

lx. Studies, Mini Study 06 - Microfinance \& Innovation. A Project for DG Enterprise and Industry. Brussels: The European Commission.

lxi. Odhiambo G. O. (2015), Innovation Strategies at The Standard Chartered Bank (Kenya)

lxii. Limited. (Unpublished MBA Project, School of Business) University of Nairobi

lxiii. OECD (2015). Oslo Manual: Proposed Guidelines for Collecting and Interpreting Technological Innovation Data. Paris.

lxiv. Olughor, R. J. (2015). Effect of Innovation on the Performance of SMEs Organizations in Nigeria, Management, 5 (3), 90-95

lxv. Orodho, A.J. (2013). Essentials of educational and social science research method. Nairobi: Masola Publishers.

lxvi. Polder, M., Leeuwen, G. V., Mohnen, P. \& Raymond, W. (2010). Product, process and organizational innovation: drivers, complementarity and productivity effects: UNUMERIT, Maastricht Economic and Social Research and Training Centre on Innovation and Technology

lxvii. Raja, M. W. \&Wei, S. (2014). Relationship between Innovation, Quality Practices and Firm Performance: A Study of Service Sector Firms in Pakistan, Journal of Management Research, 6 (4), 124-140

lxviii. Rogers, E. M. (2015). Diffusion of Innovations. (4thEd.). New York: The Free Press.

lxix. Rosli, M.M., Sidek, S. (2013). Innovation and firm performance. Evidence from Malaysian small and medium enterprises. University Malaysia Kelantan, Malaysia.

lxx. Salim, I.M., \& Sulaiman, M. (2011). Impact of organizational innovation on firm performance. Evidence from Malaysian based ICT companies.

lxxi. Sampong, W.Y. (2015). Effect of bank innovations on performance of universal banks in Ghana. Unpublished MBA Thesis, Kwame Nkrumah University of Science and Technology, Ghana.

lxxii. Saunders, M., Lewis, P., \& Thornhill, A. (2009). Research methods for business students. (5th Ed.). London: Prentice Hall.

lxxiii. Shqipe, G., Gadaf, R. \& Veland, R. (2013). Innovation Strategies and Competitive Advantages (2013). Modern Economics: Problems, Trends, Prospects, 8 (1), 10-26

lxxiv. Simiyu, B. (2013). Effects of innovation strategies on performance of commercial banks in Kenya, International Journal of Social Sciences and Entrepreneurship, 1 (3), 198-207

lxxv. Stradomski, M. (2016). Innowacjefinansowe w kreowaniuwartościprzedsiębiorstwa. Poznań: AE w Poznaniu, Grafika

lxxvi. Stewart, B. (2012). Market Myths. In Chew, D. H. (Ed.). (2001) The New Corporate Finance: Where Theory Meets Practice, p. 35-50. New York: Irwin 
lxxvii. Tavitiyaman, P., Zhang, H. Q. \& Qu, H. (2012). The Effect of Competitive Strategies and Organizational Structure on Hotel Performance, International Journal of Contemporary Hospitality Management, 24 (1), 140-159.

lxxviii. Therrien, P., Doloreux, D. \& Chamberlin, T., (2011), Innovation novelty and (commercial) performance in the service sector: A Canadian firm level analysis, Technovation, 31, 655-665

lxxix. Tidd, J. (2016). A Review of Innovation Models. London: Tanaka Business School

lxxx. Varis, M. and Littunen, H. (2010). "Types of Innovation, Sources of Information and Performance in Entrepreneurial SMEs, European Journal of Innovation Management, 13 (2), 128-154.

lxxxi. Vernon, W.R., \& Hayami, Y. (2014). Toward a theory of induced institutional innovation. University of Minnesota, Minneapolis, Minnesota.

lxxxii. Yilmaz, C., Alpkan, L., Ergun, E. (2015). Cultural determinants of customer- and learning-oriented value systems and their joint effects on firm performance, Journal of Business Research, 58, 1340-1352.

lxxxiii. Zemplinerova, A. (2010). Innovation Activity of Firms and Competition.

lxxxiv. Politickáekonomie, (6), 747-760.

lxxxv. Zhang, J., \& Duan, Y. (2010). The Impact of Different Kinds of Market Orientation on product innovation. Journal of Applied Psychology, 849-867

lxxxvi. Zhou, K. Z., \& Wu, F. (2010). Technological capability, strategic flexibility, and product innovation. Strategic Management Journal, 31 (5), 547-561

lxxxvii. Zikmund, G.W., Babin, B.J., Carr, C.J., \& Griffin, M. (2010). Business research methods. (8th ed.). South-Western, Cengage Learning.

lxxxviii. Žižlavský, O. (2011). Involving customers in the innovation process as a means leading to increasing business performance, Journal of Competitiveness, 3 (1), 15-24. 